\title{
The Image of the Kuzbass Ski Resort Sheregesh in the Discourse of Online Reviews
}

\author{
Irina V. Saveleva and Natalia V. Melnik* \\ Kemerovo State University \\ 6 Krasnaya Str., Kemerovo, 650000, Russia
}

Received 28.10.2018, received in revised form 28.12.2018, accepted 10.01.2019

\begin{abstract}
The paper addresses the problem of destination image building in the discourse of tourist reviews. Modeling the image of the popular Siberian winter resort Sheregesh is conducted on the material of the Internet websites, a space where tourists increasingly share their posttrip opinions on the place. The study distinguishes the two levels of the tourist destination image construction: macro-textual and micro-textual. Having analyzed the macrostructure of tourist review discourse, authors assume that the micro level of this discourse (particular texts) is partially predetermined by its macro-level organization. The functional attributes, such as nature, climate, ecology, cultural events, sporting activities, infrastructure, human factor constitute cognitive layer of the image. They are discussed by tourists as a part of the website policy and translate the general communicative goal of this type of discourse. A cognitive component of the discourse of opinions co-exists with emotional evaluation. The results of the image reconstruction of the Kuzbass ski resort in the discourses generated by ordinary speakers have implications for further implementation in the sphere of tourism management as well as discourse studies.
\end{abstract}

Keywords: Sheregesh, the discourse of online reviews, discursive representation, content component, evaluation component, macro level, micro level.

This work was supported by grant No. 18-412-420003 r_a "Kuzbass: Complex Cognitivediscursive Study of the Regional Image" from the Russian Foundation for Basic Research and the government of Kemerovo region, Russian Federation.

Research area: philology.

Citation: Saveleva, I.V., Melnik, N.V. (2019). The image of the Kuzbass ski resort Sheregesh in the discourse of online reviews. J. Sib. Fed. Univ. Humanit. soc. sci., 12(1), 137-154. DOI: 10.17516/1997-1370-0385.

(C) Siberian Federal University. All rights reserved

* Corresponding author E-mail address: saviren1973@mail.ru; saikova@mail.ru

ORCID: Irina Saveleva 0000-0003-4437-8489; Natalia Melnik 0000-0001-9390-5842

This work is licensed under a Creative Commons Attribution-NonCommercial 4.0 International License (CC BY-NC 4.0). 


\section{Introduction}

Nowadays, the representatives of social and humanitarian knowledge are interested in many regions of the Russian Federation and particularly in their discursive representation. Siberian region as a whole and its individual cities are studied in order to form the territorial image of the Trans-Urals (Lukashevich, 2017; Malysheva, 2016; Orlova, Ivanova, 2014; Sushnenkova, 2011).

From the point of view of Sushnenkova I. A., the use of linguo - cognitive approach in the analysis of regional image along with traditional marketing study gives an opportunity to obtain a multifaceted representation of the region image, to reveal its implicit characteristics (Sushnenkova, 2011). The specificity of Omsk discursive representation is studied in the works of Malysheva E.G. The authors focus on the media component of the territory's image, constructing a media image of Omsk on the material of mass - informational television discourse (Malysheva, 2016). Linguistic-cognitive modeling of the Siberian region image is performed in the monograph of Terskikh M.V. The author investigates the formed stereotypical image of Siberia ingrained in the mind of native English speakers. According to Terskikh M.V., the image of Siberia is still largely based on stereotypes and most of them do not correspond to reality, therefore "the task of correcting negative stereotypes and strengthening positive ones in order to form the desired image of Siberia is very urgent, and it is able to strengthen not only its own positions, but also the position of Russia" (Terskikh, Malenova, 2015: 137). It is interesting to study the research of the one of the Siberian region's symbols - lake Baikal, which is considered in the cognitive aspect and is positioned as a concept, which significant part is represented by an axiological component (Gorbunova, 2016).

On the one hand, the study coverage of regional images and territorial image is quite high, and on the other hand, the main empirical source of most studies is traditional and new media. To date, the development of network journalism, that is, the participation of ordinary citizens in the formation of the tourism discourse, takes a significant place, and sometimes it is more important for most consumers of the tourism product. In order to find a destination suitable for relaxation, citizens are increasingly turning to the non-professional (amateur) segment of tourist websites. The discourse of reviews is expanding and becoming more important for the views formation about the territory (Govorunova, 2014).

\section{Theoretical framework}

Understanding the specificity of the image in linguistics is primarily associated with the methodology of cognitive-discursive paradigm. The complexity and multilayering 
are key categories of the image, which are comprehended variably and they represent the basis for typology and parameterization (Schwaighofer, 2014). It is also important to understand the image as an ambivalent category, which goes back to perception of the subject and formation of figurative and rational-logical components of the meaning. According to Sternin I.A., "the image of the object consists of the reflection of the individual sides of the item, amenable to sensory perception" (Sternin, Rosenfield, 2008: 203). All this applies to the image of a tourist object: it is formed as a result of reflection of different facets of one object in the mass consciousness, in our case, one general picture is formed from individual associations, opinions, comparisons, assessments; it is collected from many details, but having integrity.

Significant feature of this study is the distinction between the concepts of "image" and "representation" in application to a spatial object. In linguistics, the image understanding is undoubtedly connected with the verbal representation of the image, intentionally "formed and cultivated" (Maslov, 2016; Kolosov, 2008). According to Kubryakova E.S., "an image is a picture that for one reason or another is intended to replace the real object or to represent a person or any other thing (from character and appearance of a person to the government and other power agencies in the eyes (perception) of other people" (Kubryakova, 2008: 9). The definition of the tourist destination image in foreign studies includes such parameters as objective knowledge, impressions, stereotypes, representations and emotional perception of an individual or a group of people about a particular place (Di Marino, 2008: 12).

As for the region image, we follow the definition suggested by Fedotova M.V., "the region image is a set of bright, characteristic key concepts, a stable simplified generalization of a large number of associations associated with a certain territory in the context of the country image" (Fedotova, 2014: 112). This study attempts to model an image of a touristic object since the concept of the image necessarily includes in it a directionality and a strategic aspect.

\section{Statement of the problem}

The touristic object is a part of objective reality, therefore, its representation in discursive practices of tourists is a reflection of direct, immediate contact with this reality. Sensory perception takes an important place in the formation of the resort image, which tourists express in a verbal (discursive) form. In this regard, language means, which help to articulate the experienced emotions, are selected and formulated by the authors of reviews to convey most clearly and accurately their positive (or negative) experience of 
contact with the touristic object. Kolesov I.Y. fairly noticed that "observer-talking" has a "special accentuation" in tourism discourse studies (Kolesov, 2017: 72).

Representation of the tourist object through the prism of evaluation gradually forms a stable image of this place in the readers' consciousness and the authors themselves.

The Kuzbass ski resort Sheregesh has lately acquired incredible ratings and wide coverage exactly in the discourse of reviews and in social networks. This is explained by the demand for equipped mountain areas for skiing and snowboarding among Russian and foreign tourists. Nevertheless, as the researchers note, in the regional picture of the world, the image of Sheregesh occupies peripheral positions (Kondratyeva, Frolova, 2018; Saveleva, 2018). In this regard, the task of studying the linguistic mechanisms of creating the image of the Siberian ski resort in non-professional touristic discourse is one of the most urgent.

\section{Methods}

In the discursive construction of the resort image, we distinguish two main levels of its formation: macro-textual and micro-textual. A macro-textual image is defined as common to a series of texts and includes the concept of building reviews formed by site moderators. The analysis of the macrostructure of the touristic review discourse shows that the micro level of this discourse (specific texts) is partially determined by its macro-level organization. This conformance is asymmetrical, however, the isomorphic structure of the discourse of touristic reviews of the ski resort Sheregesh at the macro and micro levels can be traced. Thus, individual websites highlight the parameters for the reviews formation, which are based on the content - factual filling of the text. On the website "Otzovik" in the section "Sheregesh, Kemerovo region, Russia" five parameters are offered in the pre-text space to assess and construct the review (Fig. 1): "Nature", "Climate", "Ecology", "Culture", "Infrastructure". Hence, the main invariant themes are determined at the macro level for creating texts-reviews of a touristic object.

On the website "100resorts.ru", we also see the thematic segmentation of discourse, but more detailed, there are nine sections: "Nature", "Climate", "Ecology", "The quality of the motorways", "Service", "Security", "Infrastructure", "Quality/Price", "Representing in the Internet", sections 4 and 8 are included in a thematic section 5 "Service" (Fig. 2).

The macrostructure of discourse reviews of the Tripadvisor.ru website is set with parameters, and their basis is the evaluation criterion presented by numerical symbol and its verbal correlate: "very good", "good", "bad", "awful" (Fig. 3). 
Отзывы - Путешествия и туризм - Курорты и экскурсии - Россия - Россия, Кемеровская область

Горнолыжный комплекс "Шерегеш" (Россия, Кемеровская область)

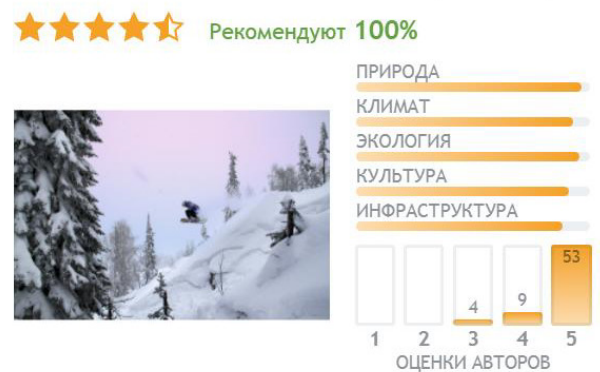

Fig. 1. Feedback interface on "Otzovik" website

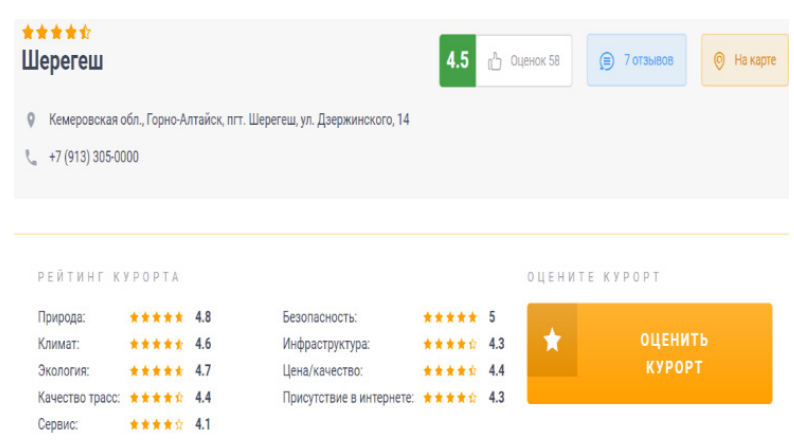

Fig. 2. Feedback interface on "100resorts" website

\section{Обзор}

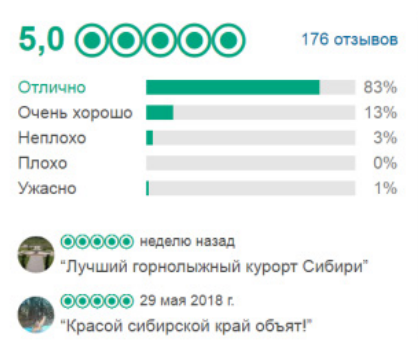

\section{РАСПОЛОЖЕНИЕ}

๑) Шерегеш, Россия

КОНТАКТНЫЕ ДАННЫЕ

므 Веб-сайт

Исправить сведения об объекте

Fig. 3. Feedback interface on "Tripadvisor" website

Structuring the website of reviews according to objective (thematic) or subjective (estimated) models does not have a direct relationship with the micro-level organization of the touristic reviews' discourse. On the contrary, these models have representation regardless of the general organization of the discursive feedback space specified by the website. 
The microtextual image of the resort is constructed through the analysis of the main thematic sections of each text, mainly revealed through the propositional structure of the texts. When analyzing the propositions of the texts of the reviews discourse, it is advisable to distinguish the following invariant sections (Table 1).

Table 1

\begin{tabular}{|l|l|}
\hline Thematic sections & Section content \\
\hline Spatial - geographical characteristics & Type of tourist object, its location \\
\hline Natural and climatic conditions & $\begin{array}{l}\text { Nature (quality of snow and mountain slopes); climate } \\
\text { (temperature amplitude, seasonal features); ecology (air) }\end{array}$ \\
\hline Cultural and sports events & $\begin{array}{l}\text { Category of the rest, significant events, atmosphere, sports } \\
\text { activities }\end{array}$ \\
\hline Infrastructure & Equipment, pricing policy; living conditions; level of service \\
\hline Human factor & $\begin{array}{l}\text { The number of tourists, attitude of the local population, } \\
\text { attitude of other tourists }\end{array}$ \\
\hline
\end{tabular}

\section{Discussion}

Since the objective and subjective characteristics of the image in the discourse are inseparable, they have a fused representation in the reviews texts about the tourist object. Nevertheless, the macro-strategy content of creating the website space determines the presence of an informative component in the text of the tourist review. Following Kubryakova E.S. and Sternin I.A., we call this component a rational layer of the image (Kubryakova, 2008; Sternin, Rosenfield, 2008). As part of the syntactic units, this component is included in the dictum part of the statement. First of all, it is a name of the tourist destination, its location defining, spatial and geographical characteristics. In the Internet reviews of the Sheregesh resort, presentation of this information has different options: from the name of the type of settlement, which the reader draws in his mind only as a point on the map, to the resort's extended description on the following parameters:

\section{Type of tourist object.}

In the discourse of reviews, toponym "Sheregesh" is categorized as follows:

a) MSR Sheregesh; MSR (mountain ski resort); sports and tourist complex; mountain ski resort;

b) village; s.u.t. - settlement of urban type.

The use of abbreviations and neutral vocabulary with a narrow meaning indicates a rational and logical representation of reality, the resort appears to the reader as a 
point on the map. Since the geographical name "Sheregesh" is polysemantic, in the texts of reviews we find a clarification, which gives rise to the expansion of the image's spatial component:

Sheregesh is a ski resort and a village with the same name Sheregesh.

2. The location of the tourist destination.

In the discourse representation, this parameter is detected at the qualitative and quantitative levels. The qualitative level is actualized in constructions of descriptive character, reflecting the relative position of the object in space:

"Sheregesh" is a sports and tourist complex, located near the village of the same name Sheregesh in the Kemerovo region; Sheregesh is located in the Kemerovo region, away from major cities.

The frequent usage of adverbs with semantics of a small distance took our attention, which complements the description of the location and contributes to the visualization of the image, more accurate representation of its location. The discursive representation of the object in the content category "Geography" forms the image of an authentic, untouched, remote Siberian village with alliterative euphonic name Sheregesh, next to which is the mountain ski complex of the same name.

The parameters of category and location of the Sheregesh tourist object in the discourse of the tourist review have a direct relationship with the following content component. In the discourse of reviews of the ski complex mandatory informative component is a description of the nature/climate conditions of the resort.

\section{Landscape.}

This informative parameter in the tourist discourse about the Kuzbass ski resort Sheregesh is presented primarily by the characteristics of mountainous terrain and woodland. Actualization of the landscape semantics occurs through attributes typical for qualitative and comparative analysis, separation the details by the type of a part/a whole and through the combination of the toponymic elements with imaginative ones (epithets and metaphorical constructions):

Mountains covered with snow-covered fir-trees, cozy tower-hotels on the slopes, shining Christmas illumination, crowds of young and cheerful people in bright sports suits. Climbing the mountain in summer, my friends and I saw the magnificent scenery, mountain valleys like Swiss, with a lot of fir trees and flowers. In some places the mountains peaks were snowy even in summer, and they shone in the sun from the 
white snow cover (Otzovik. Available at: https://otzovik.com/review_4241382.html Accessed: 20.07.2018.).

The main accent is made on the tops and slopes of the mountains, which is pragmatically justified by the specifics of the ski resort as an object of interest to a certain social group - people of an active lifestyle, seeking to conquer new tops. This thesis is confirmed by the following statement:

But if you come here for skiing, then everything else is not so important-the main things are mountains and You.

The semantics of the landscape is actualized in connection with the description of the resort location and sports theme, which also forms a volumetric image, symbolizing the breadth of the Siberian region:

The ski resort "Sheregesh" is located immediately on the 3 mountains: Zelyonaya, Mustag and Utuya. The main part of the slopes and infrastructure is located on the mountain Zelyonaya. The slopes of Mustag and Utuya are mainly chosen by freeriders; At the top of these mountains there are vast untouched snowfields - a joy for the novice freeriders (Otzovik. Available at: https://otzovik.com/review_148959.html Accessed: 21.07.2018).

4. Climate.

A special place in the discourse of reviews about the ski resort Sheregesh is a description of the area climate. Most of the resort life takes place in winter, so in the discourse of reviews the winter weather is mainly characterized, which is associated primarily with the Siberian region, and a stereotype of this climate is often justified: Siberia is known for its Siberian climate. It means a lot of snow and a lot of frost. The temperature often falls below $-25^{\circ} \mathrm{C}$. We were in Sheregesh in March, and missed severe frosts - the lowest temperature was $-18{ }^{\circ} \mathrm{C}$ and only in the morning, by noon it rose to a comfortable -11-12 ${ }^{\circ} \mathrm{C}$. But a trip in spring does not guarantee the absence of low temperatures (Otzovik. Available at: https://otzovik.com/review_1618542.html Accessed: 21.07.2018).

The image of Siberian climate has binary manifestation. On the one hand, the weather is unpredictable, the temperature amplitude is not comfortable for tourists. The reviewers employ emotional graphics, epithets, explanatory constructions in the emphatic function, which indicate the delight, elated mood of the authors rather than the spectrum of negative emotions: The view from the top of the mountain is just amazing... the heart freezes from the neighbouring mountains' view ... and also from the wind that wafts away snowboards, as well as from a coming windstorm. 
(Tripadvisor. Available at: https://www.tripadvisor.ru/ShowUserReviewsg2535592-d7393665-r305804517-Mountain_Zelenaya-Sheregesh_Kemerovo_Oblast_ Siberian_District.html Accessed: 21.07.2018).

On the other hand, the weather conditions in Sheregesh in winter make only a positive impression on guests of the resort, who came to Siberia from the European part, that is commented through the semantics of authenticity, for example, in the lexeme "real":

There's real winter and always a lot of snow!

Last time we skied in a snowstorm - that's a real extreme.

Substantial dominant, actualizing this component in the reviews, is the description of the snow cover, which appears not only as part of the winter nature of Sheregesh, but also as an essential factor that performs the following functions:

a) main attraction of the resort, giving it a uniqueness:

You need to understand that people come here not for on-piste skiing but for a powder within walking distance; a lot of snow in any year from November to May.

b) a reason for pleasant feelings:

White snow crunched under my feet and we did not want to leave this Wonderful place! We were at the end of March-the snow was melting a little, but it did not stop to get a lot of fun! Such amount of snow as in the middle of March of this year, I have not seen, perhaps, ever! The mountain was like a feather-bed of down and cotton wool! We scurried between the trees, jumped into the snowdrifts.

c) a cause of discomfort, danger:

Spiny snow got under the neck-piece, and the wind tried to drive away us from the mountains; there is always so much snow and if to move slightly to the side from the slopes, it is possible to fall into snow till the shoulders; one of acquaintances even called out the snowmobile, because he was not able to get out.

d) an opportunity for free-ride (off-piste skiing), connected with important snow quality (loose, airy structure, like fluff, natural origin) and weather conditions:

Snow has an air texture, that is unusual for the Urals, flies in all directions; Go under the snow falls and you surely find your piece of not smoothed powder in the woods, in an outrun or in a ski-tour (Tripadvisor. Available at: https://www.tripadvisor. ru/LocationPhotoDirectLink-g2535592-d7393665-i162179821-Mountain_ZelenayaSheregesh_Kemerovo_Oblast_Siberian_District.html Accessed: 26.07.2018.).

e) a symbol of untouched, virgin, mysterious nature:

Some separate peaks with powder and few people (lots of spirits). 
Since the mountainous part of the resort Sheregesh is the main territory of the tourist object, a description of natural and climatic conditions is closely intertwined with a description of skiing runs, so the next component is an infrastructure. Specifics of the resort are winter sports, so the conditions created on the territory of the tourist destination are of great importance for tourists. This is certainly reflected in the discourse of reviews. First of all, the territory of the ski resort and its facilities are described in details.

5. Snow skiing runs and lifts.

Statements of a general nature, in propositions of which this thematic section is actualized, are rather an exception for the discourse of reviews than a rule, but they also actualize the semantics of the quantity:

Sheregesh has magnificent ski slopes, there are eleven, as well as sixteen different lifts, which suit any taste.

The semantics of a sufficient number of objects for sports is also reflected in the use of lexical repetitions, antonyms and synonyms in the texts of reviews:

There are many lifts (in winter they are closed at 16-45), a lot of restaurants and cafes on the mountain. Lots of lifts: tablet lift, open and closed chair lifts, car lifts. On the mountain and at the foot there are many cafes, restaurants and hotels. There are many places where you can rent equipment and hire instructors.

Ski runs in Sheregesh, as well as lifts, are a "resort-forming" factor, therefore, subject to categorization and classification. For example, in the discourse of reviews written by professional athletes, the tracks have a different color designation:

If in Austria the ski run offers the same level of difficulty, here the upper section may be red and black, the middle is blue, and sometimes the lower flat part suggests even the use of ski sticks for further movement forward.

Most of the official names in Sheregesh have their colloquial analogues. Ordinary native speakers on a subconscious level simplify, modify many of the names, and include a figurative or an associative component in the name (for example, a breadbin (khlebnitsa) is a lift, which is shaped like a loaf of bread). As you know, words containing this component are easier to remember: The ski resort pleases with a variety of ski runs and ski lifts. There are two-seated ski lifts, and a four person chair lift with protective transparent hubcap, called "breadbin", and comfortable booths on the far side. And of course the good old bar lifts are present; it is especially worth mentioning the ski run named after Tuleyev (dollar or bread slicer), which was built either for 
the Championship, or for the World Cup. It has radically changed the skiing area, as it starts from the next mountain top.

6. Service level. Pricing policy.

The level of equipment of the complex Sheregesh often becomes the object of criticism. It is no accident that the discourse of reviews is gaining popularity among potential tourists today. The factor of objectivity, based on coexistence in both macroand micro-discursive space of polar opinions, contributes to the establishment of trust and communicative assonance between the participants of the feedback discourse. As a result of the perception of texts compiled by "tourists like me", the authors of reviews in the social and communicative space of readers take the position of "Ours".

Anthropogenic objects are mainly criticized: the opening hours of the cable car, the lighting of ski runs, transport, which can take you to the ski zones, service in cafes, rent of housing. At the top of the rating of critical reviews is the price policy of the complex and the queue:

Drawbacks - ski lifts are closed at 16.45. Large queues, and the fact that ski lifts have different owners, and you need to buy a separate ski pass for each one, it is very uncomfortable! There is no way to check the card status on the spot, only at the box office, because of that you can queue and be with a lack of funds in the account, it is difficult to control when you have several different ski passes; Prices. For ski lifts, for example, prices can reach the mark of 200 roubles, agree, the amount is not small. What to say about the prices for entrance, accommodation, food and other services. My husband and I found the prices unreasonably high.

Thematic block "Sporting and cultural events" compositely and meaningfully harmonizes with the previous one. Analysis of the discourse of reviews shows that it is also discussed in detail by the participants of the discourse. For example, some visitors of the ski complex are not interested in sports, and therefore Sheregesh in these texts is positioned as a place of rest, is an alternative to skiing and snowboarding:

And even if you do not know how to ski, you can rent a snowmobile, or take a snowmobile excursion to the famous places of Sheregesh, you can just walk through the beautiful places surrounded by snow-covered pine trees. You can ride on the closed convenient lifts to the top of the mountain and enjoy the beautiful views from the viewing platforms. Nobody gets bored in Sheregesh.

Description of cultural events is concentrated around the world-famous festival of skiers and snowboarders during the spring mass descent in bathing suits, named 
after the local cafe "Grelka". Festival "Grelka-fest" today is a brand for the Kuzbass ski resort. For this reason, the mention of the cafe-bar "Grelka" and its location on the mountain Zelenaya is connected with the food point, which is often associated with the "carnival" atmosphere of the resort:

I went to the bar - Grelka. The food is very tasty and they make cocktails; bar Grelka is tasty, but not cheap; moreover, you can feel here a great atmosphere of Gesh; I liked the famous Grelka; who is going to be there, try their burgers, yummy) and an entertainment event:

Sheregesh often becomes a venue for festivals and competitions, then here come different athletes and not only from Russia; Mountain Zelyonaya is not only a ski track, but also a venue for events such as the descent in bathing suits, costumes carnival.

The texts of the reviews also present thematic unit "Human factor", which is not specified on the macro-level. The ambiguous attitude of tourists to fellow citizens receives a corresponding representation in the discourse of reviews. On the one hand, mass appeal attracts when it comes to holidays and carnivals, on the other hand, disappoints in the frame of "waiting": Queues are incredible, the resort is very popular, so many people tend to get there, apparently, the resort simply cannot cope with such an influx of customers, or they do not have a well-established system of work with customers, in general, whatever they have, the fact remains the fact, the queue is a problem of Sheregesh.

The description tonality of the category "People" attracts. It varies from sinceregood-natured to ironic:

Aborigines are very friendly towards visitors, can tell about and show everything, and answer the questions; but at other times on the mountain you can see a lot of interesting characters; Gesh - is a positive place where skiers and snowboarders do not argue about who of them are ahead - they found a compromise; And people in Sheregesh are very kind and honest, many times I have seen their ads and messages posted in the social networks about found cameras and camcorders.

The sufficient component of the discourse of reviews co-exists with the emotional-evaluative, due to the specifics of the Internet review. The creation of reality in a personal discourse, which is the discourse of the review, according to Tchernyavskaya V.E., takes place in a such format, when the representation and perception of any fragment of reality is inseparable from the evaluative attitude to it (Tchernyavskaya, 2014: 44). 
This component is contained in the feedback modus and reflects the emotions and experiences of the authors who visited Sheregesh. As shown above, the moderators of some sites specified in advance the ranked or evaluative approach of the review design. Therefore, the next stage of the analysis concerns those fragments of discourse, which reflect the overall assessment of the resort. General and complete characteristic of the resort is an essential component in the formation of its discursive image. Here, an important aspect of the analysis is a personality of the author, an area of his social preferences and a motive for visiting the resort. Most of the texts of the discourse reviews contain elements of personal narrative (identity narrative), where the author talks about the resort as a fragment of his biography. The reason for the emotional saturation and sometimes oversaturation of the discourse of reviews is that they capture a significant part of the life continuum. The General impression is actualized in statements that reflect not one, but a whole range of feelings and emotions. Their conceptualization generates an image fixed by means of language, formed by the author in accordance with his linguistic repertoire. Having carried out a targeted selection of statements with the overall assessment of the resort, we conducted an analysis at the micro-level and received the following results:

1) In the statements semantics, giving an overall assessment to the tourist object, also substantial dominants are highlighted, which partially correspond to the mentioned above:

Sheregesh is called the second Switzerland. And this is absolutely true. After skiing on the wet slopes of Petersburg Sheregesh - it's a kaif! The best skiing in the Urals! (Geography).

For lovers of ski resorts Sheregesh-must be in wish list!! Not worse than European resorts for sure! Sheregesh for many years remains the Mecca of snowboarding and skiing in Siberia, what else can you add... (Geography / Sport).

Liked everything up to squeals! Such freeride was met neither by me nor by more experienced freerides from our company. To all fans of winter sports, I recommend to visit the Sheregesh (Sport).

The resort is for those who want to relax from the city. (Recreation / Infrastructure).

Ski resort Sheregesh is an amazing place for outdoor activities in winter and autumn, summer and spring! (Recreation / Sport / Nature).

2) In the representation of general assessment, a significant part of the statements is constructed in the form of nominative constructions containing an abstract noun, a place denoting an indefinite space in terms of volume and arrangement. For many tourists who visited The Mountainous Shoria, Sheregesh is a place that provides a 
certain activity component, so the nominative constructions in this case include verbs with the semantics of stay and movement:

Sheregesh is a place which you should definitely visit; A place where you want to come back!!!; A place where Ministers, Deputy Ministers, and even the President come to have rest.

Positive-enthusiastic mood that influenced the overall evaluation statement, verbalizes with a help of evaluative lexicon of neutral and low register, and emphatic constructions:

One of the best ski resorts in Russia! Great place to have a rest! Wonderful place!

3) Giving an overall assessment of the Siberian resort, the authors of reviews often tend to use more literary, poetic, song vocabulary, and figurative means. Intertextuality as a phenomenon that has a more significant effect on the reader is manifested in connection with the actualization of the block "Natural conditions":

The region is seized by the Siberian beauty! Only mountains can be above the mountains; A snow-white fairy tale or the Kingdom of the Snow Queen! The maximum of drive and positive emotions can be obtained in this wonderful corner of the Kuzbass nature.

As it can be seen, the literary expression a marvelous corner of nature, which has a status of cliche in the Russian language, syntagmatically combined with the phrase, which includes neologism drive, with a subject of extremely excited state.

4) Critical understanding of the tourist experience occupies a significant part of the discourse of reviews. Therefore, a negative assessment is given too in the category of "General impression". It consists not only of the subjective preferences of individual tourists, but also objectively reflects the situation. Critical evaluation is ranked from balanced consisting of pros and cons to negative, which can be expressed explicitly in the discourse of reviews:

We went there with friends in the winter, in principle, we liked it, except for some nuances; Sheregesh is behind in everything except prices;

or maybe implicitly, by means of graphic techniques to indicate the effect of unspoken words or it is completed by the reader:

So Sheregesh is good, but... I want to go back to the Alps.

\section{Conclusion/Results}

In conclusion, we note that the image of the resort Sheregesh on an objective and meaningful level appears as quite remote and cold, but characterized by spatial latitude, 
suitable natural conditions and presence of sufficient territory for skiing. Therefore, the objective representation of the Siberian resort in the discourse contributes to its positioning as an authentic and at the same time equipped tourist facility.

Much brighter image of the Kuzbass resort is formed at the subjective-evaluative level. The emotional background of reviews is so high that the resort becomes an attractive place in the minds of readers, which is shown as absolutely worth visiting. The picture, which the tourists construct by using different multi-level figurative language means, as well as with the help of graphics and visual components (photos), filled with emotions, and all of these attracts to the tourist object much stronger than advertising websites and brochures. Making an impact on the readers, the language of reviews imprints in their mind a verbal image of a fabulous place, which everyone must visit.

\section{References}

Di Marino, E. (2015). The Strategic Dimension of Destination Image. An analysis of the French Riviera image from the Italian tourists' perceptions. $\mathrm{PhD}$ Tourism Management. University of Naples "Federico II". Faculty of Economics, available at: http://www.esade.edu/cedit/pdfs/papers/pdf10.pdf (accessed: 12.06.2018).

Fedotova, A.V. (2014). Formirovanie obraza Murmanskoj oblasti v poligraficheskoj reklame regiona [The formation of Murmanks oblast image in printed advertisements of the region]. In Obschestvo. Sreda. Razvitie [Society. Environment. Development]. Saint Petersburg, 2, 112-116.

Govorunova, L.Yu. (2014). Rechevoj zhanr «internet-otzyv turista»v russkoj $i$ ital'yanskoj lingvokul'turah [Speech genre 'internet feedback of a tourist' in Russian and Italian linguocultures]. Cand. of Art Diss. Volgograd, 25 p.

Gorbunova, L.I. (2015). Bajkal kak central'nyj `element konceptosfery sibiryaka [Baikal as a central element of a Siberian's conceptual sphere]. In Tomsk university bulletin. Philology, 1 (33), 5-15.

Kolesov, I.Yu. (2017). Turisticheskij diskurs: aktualizaciya vzglyada nablyudatelya [Tourist discourse: observer's view actualization]. In Lingvokul'turnoe prostranstvo turisticheskogo diskursa: universal'nye, nacional'nye $i$ regional'nye prioritety $i$ napravleniya: materialy mezhdunarodnoj nauchno-prakticheskoj konferencii [Linguocultural space of tourist discourse: universal, national and regional priorities and directions: materials of intern. sci. conf.]. Barnaul, 71-76.

Kolosov, V.A. (2008). Geograficheskie obrazy i geopoliticheskie predstavleniya: puti formirovaniya $\mathrm{i}$ podhody $\mathrm{k}$ izucheniyu [Geographical images and geopolitical 
presentations: ways of formation and learning approaches]. In Vestnik Dal'nevostochnoj gosudarstvennoj social'no-gumanitarnoj akademii, 1, Humanities, 1, 72-91.

Kondratyeva, O.N., Frolova T.I. (2018). Obraz regiona v obydennom yazykovom soznanii ego zhitelej (na primere obraza Kuzbassa) [The Image of Region in ordinary language Consciousness of its Residents (on an Example of the Image of Kuzbass)]. In Psycholinguistics, 24(2), 78-97.

Kubryakova, E.S. (2008). K opredeleniyu ponyatiya imidzha [On the definition of the concept 'Image'], available at: https://cyberleninka.ru/article/n/k-opredeleniyuponyatiya-imidzha.pdf (assessed: 26.07.2018).

Lukashevich, E.V. (2017). Altaj turisticheskij glazami zhurnalista: mul’timedijnye istorii v regional'nyh SMI [Touristic Altai through the eyes of a journalist: multimedia stories in the regional media]. In Lingvokul'turnoe prostranstvo turisticheskogo diskursa: universal'nye, nacional'nye $i$ regional'nye prioritety $i$ napravleniya: materialy mezhdunarodnoj nauchno-prakticheskoj konferencii [Linguocultural space of tourist discourse: universal, national and regional priorities and directions: materials of intern. sci. conf.]. Barnaul, 95-98.

Malysheva, E.G. (2016). Formirovanie mediaobraza regiona v federal'nyh televizionnyh SMI (na materiale tekstov ob Omske) [Formation of regional media image (case study of Omsk discourse)], In Nauchnyj dialog [Scientific dialogue], 12 (60), 134-144.

Maslov, V.N. (2016). Obraz Kaliningradskoj oblasti na stranicah gazety «Kaliningradskaya pravda» sovetskogo vremeni [The image of Kaliningradskaya oblast on the pages of Soviet paper 'Kaliningradskaya Pravda']. In Kant Baltic Federal University Bulletin. Humanities and Social Sciences, 3, 25-35.

Orlova, V.V., Ivanova, E.S. (2014). Mental'nye obrazy goroda Tomska (na primere studentov universiteta) [Mental representations of Tomsk (case study of university students)]. In Saint Petersburg University Bulletin, 12: Sociology, 1, available at: https:// cyberleninka.ru/article/n/mentalnye-obrazy-goroda-tomska-na-primere-studentovuniversiteta (assessed: 26.07.2018).

Saveleva, I.V. (2018). Kuzbasskij gornolyzhnyj kurort Sheregesh v diskurse turisticheskoj destinacii [Kuzbass ski resort Sheregesh in tourist destination discourse]. In Mir nauki, kultury, obrazovaniya [The world of science, culture and education], 4 (71), 524-525.

Schwaighofer, V. (2014). Tourist Destination Images and Local Culture: Using the Example of the United Arab Emirates. Springer Gabler, 120 p. DOI: 10.1007/978-3658-04521-0. 
Shepel', V.M. (2002). Imidzhelogiya. Kak nravit'sya lyudyam [Image studies: how to make a positive impact on people]. Moscow, $345 \mathrm{p}$.

Sternin, I.A., Rosenfield, M.Ya. (2008). Slovo $i$ obraz [A word and an image], Voronezh, 243 p.

Sushnenkova, I.A. (2011). Lingvokognitivnoe issledovanie regional'nogo imidzha (na primere Omskoj oblasti) [Linguocognitive study of regional image (case study of Omsk oblast)]. Cand. of Art Diss. Omsk, 25 p.

Terskikh, M.V., Malenova, E.D. (2015). Mediaobraz sibirskogo regiona: lingvokognitivnoe modelirovanie [Media image of Siberian region: linguo-cognitive modeling]. Omsk: LITERA, 160 p.

Tchernyavskaya, V.E. (2014). Lingvistika teksta. Lingvistika diskursa. [Lingistics of text. Linguistics of discourse]. Moscow: Librocom, 203 p.

Yaranceva, D.D. (2014). Formirovanie i konstruirovanie obraza goroda sredstvami reklamy i PR (na primere goroda Ekaterinburga) [Formation and construction of a city image by means of advertising and PR (case study of Ekaterinburg)]. In Sovremennyj gorod: social'nost', kul'tury, zhizn' lyudej Materialy XVII Mezhdunarodnoj nauchnoprakticheskoj konferencii [Modern city: Social culture, people's life. Materials of XVII intern. Sci. conf.]. Ekaterinburg, 393-397.

\section{List of sources}

Reviews. Travel and tourism. Resorts and excursions. Russia. Russia, Kemerovo region. Mountain ski resort Sheregesh, available at: https://otzovik.com/reviews/ gornolizhniy_kompleks_gornaya_shoriya_russia_kemerovskaya_oblast/

Russia. Siberian federal district. Kemerevo region. Sheregesh, available at: https://www.tripadvisor.ru/ShowUserReviews-g2535592-d7393665-r595640262Mountain_Zelenaya-Sheregesh_Kemerovo_Oblast_Siberian_District.html

Reviews about the ski resort Sheregesh, available at: https://100resorts.ru/resorts/ gornolyzhnye/sheregesh/reviews/ 


\title{
Образ кузбасского горнолыжного курорта Шерегеш в дискурсе интернет-отзывов
}

\author{
И.В. Савельева, Н.В. Мельник \\ Кемеровский государственный университет. \\ Россия, 650000, Кемерово, ул. Красная, 6
}

В статье рассматриваются основнье составляющие дискурсивного образа кузбасского горнолыжного курорта Шерегеш. Моделирование образа туристического объекта выполнено на материале интернет-отзывов.

В исследовании было разграничено два уровня формирования образа туристического объекта: макротекстовый и микротекстовый. Анализ макроструктуры дискурса туристического отзыва показывает, что микроуровень данного дискурса частично определяется его макроуровневой организачией: природно-климатические условия (природа (качество снега, горных склонов); климат (амплитуда температур, сезонные особенности); экология (воздух)); культурно-спортивные мероприятия (категория отдыха, значимые события, атмосфера, спортивная деятельность), инфраструктура (оборудование, ценовая политика; условия проживания; уровень сервиса); человеческий фактор (количество отдыхающих, отношение местного населения, отношение других туристов). Содержательный компонент дискурса отзывов сосуществует с эмочионально-оценочным.

Результаты реконструкиии образа кузбасского горнольжного курорта на материале показаний языкового сознания рядового носителя языка могут быть использованы в рекламе туристического объекта.

Ключевые слова: Шерегеш, дискурс интернет-отзывов, дискурсивная репрезентация, содержательный компонент, оченочный компонент, макроуровень, микроуровень.

Работа выполнена при поддержке гранта № 18-412-420003 p_a «Кузбасс: комплексное когнитивно-дискурсивное исследование образа региона» Российского фонда фундаментальных исследований и Администрации Кемеровской области Российской Федерации.

Научная специальность: 10.00.00 - филологические науки. 